\title{
PERANCANGAN SISTEM INFORMASI MANAJEMEN KNOWLEDGE BERBASIS WEB DI PRODI SISTEM INFORMASI UNIVERSITAS TERBUKA
}

\author{
Dian Nurdiana \\ Program Sistem Informasi Universitas Terbuka \\ Jl. Cabe Raya. Pondok Cabe Pamulang. Tangerang Selatan 15418, Banten,Indonesia.
}

dian.nurdiana@ecampus.ut.ac.id

\begin{abstract}
Knowledge management is needed right now, but many companies or institutions are constrained in conducting knowledge management because of the limitations of the information system. In Information Systems Study Program Universitas Terbuka still uses a manual system that uses Windows file explorer. This results in the difficulty of sharing information with outsiders. Therefore we need a web-based knowledge management information system design that can solve problems so far. The design model in this article uses the Unified Modeling Language (UML) model, which is a structural model and techniques for modeling object-oriented program (OOP) design. The results of the design of knowledge management information systems are expected to be able to help develop software later.
\end{abstract}

Keywords: information systems, knowledge management, Unified Modeling Language (UML).

\begin{abstract}
Abstrak - Knowledge manajemen merupakan hal yang dibutuhkan saat ini, namun banyak perusahaan atau lembaga terkendala dalam melakukan knowledge manajemen karena keterbatasan sistem informasi. Di Prodi Sistem Informasi Universitas Terbuka masih menggunakan sistem manual yaitu menggunakan windows file explorer. Hal ini mengakibatkan sulitnya berbagi informasi dengan pihak luar. Oleh sebab itu dibutuhkan sebuah perancangan sistem informasi manajemen knowledge berbasis web yang bisa menyelesaikan permasalahan selama ini. Model perancangan pada artikel ini menggunakan model Unified Modeling Language (UML) yaitu model struktur dan teknik untuk pemodelan desain program berorientasi objek (OOP). Hasil yang dari perancangan sistem informasi manajemen knowledge ini diharapkan bisa membatu pengembangan perangkat lunak nantinya.
\end{abstract}

Kata Kunci: sistem informasi, manajemen knowledge, Unified Modeling Language (UML).

\section{PENDAHULUAN}

Dewasa ini pengkajian terhadap knowledge management sudah banyak dilakukan utamanya untuk implementasi terhadap organisasi-organisasi atau divisi-divisi pada suatu perusahaan atau lembaga, bahkan untuk penggunaan lembaga tersebut secara umum. Pengkajian terhadap knowledge management ini dititik beratkan kepada seberapa besar pengaruh knowledge management terhadap utilitas proses bisnis suatu lembaga. Mengelola knowledge berarti mendayagunakan knowledge yang ada, baik knowledge dari masing-masing individu maupun hasil knowledge dari hasil diskusi kelompok yang digunakan untuk kebutuhan proses bisnis suatu perusahaan. Faktor yang mempengaruhi lingkungan bisnis saat ini bukan lagi era informasi, tetapi sudah beralih ke era pengetahuan. Pengelolaan knowledge tersebut dimodelkan dalam suatu sistem yang dinamakan
Knowledge Management [1] .

Untuk saat ini pengelolaan di prodi sistem informasi universitas terbuka masih menggunakan metode manual, yaitu dengan menggunakan Windows File Explorer yang terkoneksi ke jaringan internal. Kelemahan metode ini adalah, sulitnya pihak dari luar untuk mengakses data tersebut, karena pihak luar harus meminta pada pihak internal untuk meminta data atau file yang diinginkan. Teknologi merupakan salah satu elemen pokok yang terdapat pada knowledge management, dikenal sebagai media yang mempermudah penyebaran explicit knowledge. Oleh karena itu, dibutuhkan knowledge management system yang terdedikasi untuk mengelola secara daring dan bisa diakses oleh berbagai pihak yang membutuhkan [2].

Berdasarkan Latar belakang yang telah dijelaskan, maka bisa diambil rumusan masalah pada penelitian ini Bagaimanakah cara merancang sebuah knowledge 
management system yang yang terdedikasi secara daring dan bisa diakses oleh berbagai pihak yang membutuhkan berbasis web di prodi sistem informasi universitas terbuka. Pengembangan sistem informasi ini menggunakan model pembangunan perangkat lunak Waterfall atau sering juga disebut Linear Sequential Model. Lima tahap yang harus dilalui dalam membangun perangkat lunak dengan model waterfall, namun pada penelitian dibatasi hanya sampai tahap Perancangan Sistem dan Perangkat Lunak (System and Software Design) karena fokus dalam penelitian ini sampai tahap perancangan [3].

Adapun tujuan yang ingin dicapai dari Penelitian Ini adalah Merancang knowledge management system yang memudahkan program studi dalam mengelola knowledge management system sehingga pengelolaan lebih baik dan bisa diakses dengan mudah dan akurat oleh dosen maupun pihak luar. Rancangan yang dihasilkan antara lain use case diagram, class diagram, activity diagram, Deployment diagram dan perancangan antar muka.

\section{METODOLOGI PENELITIAN}

Desain penelitian adalah representasi langkah-langkah yang dilakukan dalam melakukan sebuah penelitian, pada produk ini, penulis membagi pengembangan aplikasi menjadi dua tahapan yaitu:

\section{A. Metode Pengumpulan Date}

1. Studi Literatur, yaitu mengumpulkan data dengan mempelajari artikel-artikel ilmiah, pernyataan resmi pemerintah, dokumen resmi pemerintah untuk memberikan pemahaman lebih lanjut tentang produk yang akan dibuat.

2. Wawancara, yaitu pengumpulan data dengan melakukan tatap muka dan tanya jawab langsung dengan para stakeholder.

\section{B. Metode Pengembangan Perangkat Lunak}

Rancang dan bangun sistem akan menggunakan model pembangunan perangkat lunak Waterfall atau sering juga disebut Linear Sequential Model. Menurut [3]menjabarkan lima tahap yang harus dilalui dalam membangun perangkat lunak dengan model waterfall, namun pada penelitian dibatasi hanya sampai tahap Perancangan Sistem dan Perangkat Lunak (System and Software Design).

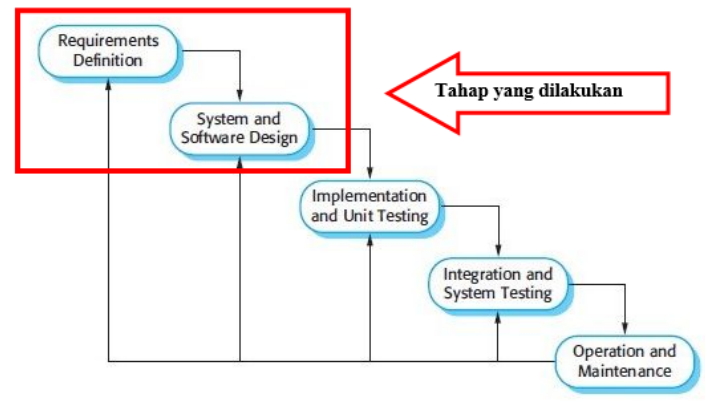

Gambar 1 tahap penelitian
Pada gambar 1 menunjukkan tahapan penelitian pada perancangan Sistem Informasi Manajemen Knowledge Berbasis Web sebagai berikut:

\section{Requirement Analysis and Definition}

Requirement Analysis and Definition adalah tahapan penetapan fitur, kendala dan tujuan sistem melalui konsultasi dengan pengguna sistem [4]. Semua hal tersebut akan ditetapkan secara rinci dan berfungsi sebagai spesifikasi sistem. Konsultasi yng dilakukan dengan pengguna sistem bisa menggunakan wawancara maupun kuisioner. Penetapan fitur terkait Requirement Analysis and Definition ini mendefinisikan bagaimana Sistem Informasi Manajemen Knowledge Berbasis Web akan dibuat sesuai dengan kebutuhan dari pengguna sistem. Mendefiniskan juga kendala-kendala yang selama ini dihadapi ketika menggunakan sistem manual.

\section{System and Software Design}

Pada Tahap System and Software Design ini akan dibentuk suatu arsitektur sistem berdasarkan persyaratan yang telah ditetapkan. Selain itu juga, dilakukan identifikasi dan penggambaran terhadap abstraksi dasar sistem perangkat lunak beserta hubungan-hubungannya. Penggambaran atau perancangan yang dibuat berdasarkan hasil Requirement Analysis and Definition yang dilakukan sebelumnya. Rancangan yang dihasilkan antara lain use case diagram, class diagram, activity diagram, Deployment diagram dan perancangan antar muka.

\section{HASIL DAN PEMBAHASAN}

Hasil dari penelitian ini berupa rancangan sistem informasi yang akan dikembangkan rancangan tersebut meliputi:

\section{A. Use case diagram}

Use case diagram yaitu salah satu jenis diagram pada Unified Modelling Language (UML) yang menggambarkan interaksi Antara sistem dan aktor, Use case diagram juga dapat mendeskripsikan tipe interaksi Antara pengguna sistem dengan sistemnya. Use case diagram menggambarkan fungsionalitas yang diharapkan dari sebuah sistem. Yang ditekankan adalah "apa" yang diperbuat sistem, dan bukan "bagaimana" [5]. 


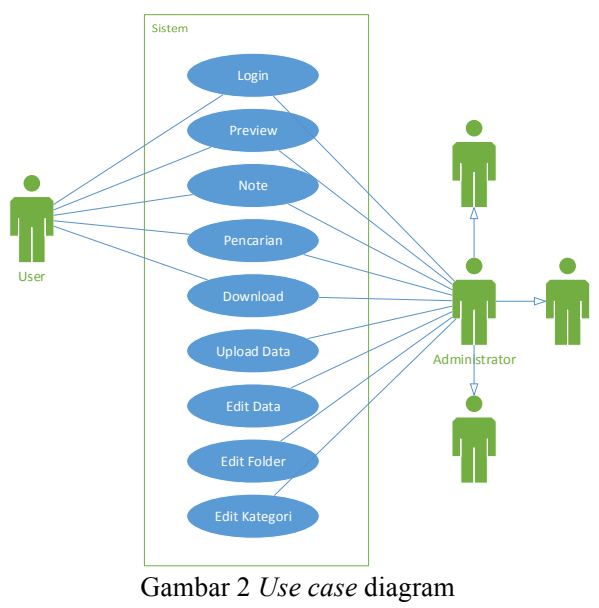

Pada gambar 2 di atas menjelaskan pengaturan hak akses pengguna pada sistem ditentukan oleh kesepakatan penugasan dengan perusahaan saat proses wawancara pada tahap analisis dan definisi kebutuhan sistem. Berdasarkan kesepakatan tersebut terdapat dua kelompok pengguna yaitu Umum dan Administrator. Sesuai pembagian kerja yang tercantum dibagian pembagian kerja, penulis hanya akan menjelaskan fitur yang penulis kerjakan, yakni Login, Preview, Edit Data, Edit Folder, dan Edit Kategori.

Pengguna tingkat Umum (User) mempunyai hak terhadap beberapa fungsi sebagai berikut:

1. Login : Aplikasi ini berbasis hak akses untuk membatasi kemungkinan perubahan yang tidak diinginkan sehingga diperlukan antarmuka Login .

2. Preview : Fitur ini digunakan untuk membaca dokumen langsung di halaman web sistem, sehingga pengguna tidak harus mengunduh berkas yang ingin dilihat.

Sedangkan untuk pengguna pada tingkat Administrator bisa terdiri beberapa admin yang mempunyai hak akses yang sama seperti pengguna Umum juga ditambah fitur-fitur lainnya sebagai berikut:

1. Edit Data : Fitur ini terdiri atas dua subfitur yaitu Hapus Berkas dan Ganti Nama Berkas. Hapus Berkas digunakan untuk menghapus berkas yang telah tidak dibutuhkan dari sistem, sedangkan Ganti Nama digunakan untuk mengganti nama suatu berkas dengan nama baru.

2. Edit Folder : Fitur ini terdiri atas tiga subfitur yaitu Tambah Folder, Hapus Folder dan Ganti Nama Folder. Tambah Folder digunakan untuk menambah folder baru kedalam sistem, Hapus Folder digunakan untuk menghapus folder yang telah tidak dibutuhkan dari sistem. Sedangkan Ganti Nama digunakan untuk mengganti nama suatu folder dengan nama baru.

3. Edit Kategori : Fitur ini terdiri atas tiga subfitur yaitu Tambah Kategori, Hapus Kategori dan Ganti Nama Kategori. Tambah Kategori digunakan untuk menambah kategori baru kedalam sistem, Hapus
Kategori digunakan untuk menghapus kategori yang telah tidak dibutuhkan dari sistem. Sedangkan Ganti Nama digunakan untuk mengganti nama suatu kategori dengan nama baru.

\section{B. Class Diagram}

Class Diagram adalah hasil analisa kebutuhan dari Use case diagram, dan merupakan model statis yang menggambarkan struktur dan deskripsi class serta hubungannya antara satu sama lain. Class Diagram merupakan hubungan antar kelas dan penjelasan detail tiap-tiap kelas di dalam model desain dari suatu sistem, juga memperlihatkan aturan-aturan dan tanggung jawab entitas yang menentukan perilaku sistem [6].

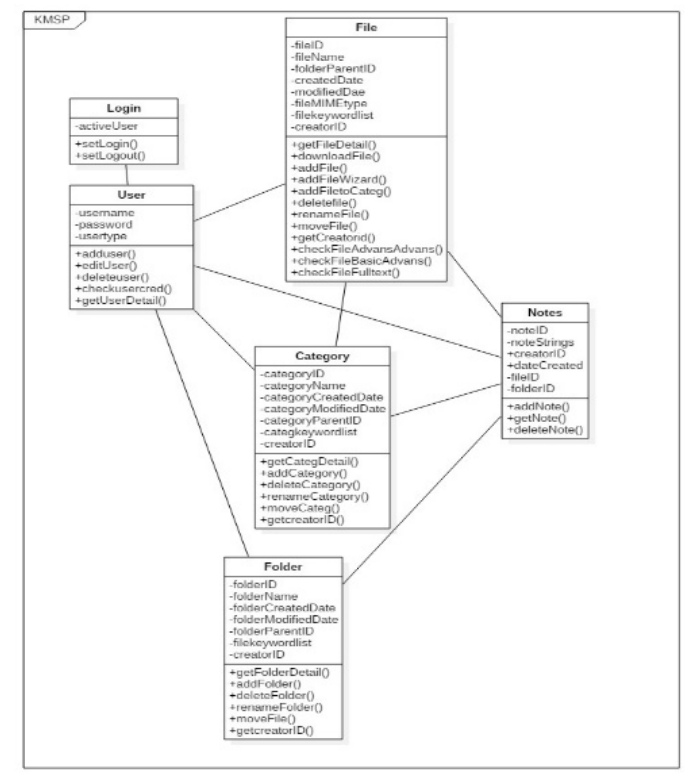

Gambar 3 Class Diagram

Pada gambar 3 menujukan hubungan kelas-kelas yang ada pada tahapan perancangan Sistem Informasi Manajemen Knowledge Berbasis Web. Kelas-kelas yang dibuat antarlain: login, user, file., category, notes dan folder.

1. Kelas login dan user mempunyai hubungan assosiasi.

2. Kelas user, file, category, notes dan folder mempunyai hubungan agregasi.

\section{Activity diagram}

Activity diagram ini menggambarkan proses bisnis dari aplikasi yang dibangun dan urutan aktivitas dalam sebuah proses yang dilakukan [7]. Activity diagram pada perancangan sistem inrformasi sebagai berikut:

\section{Admin}




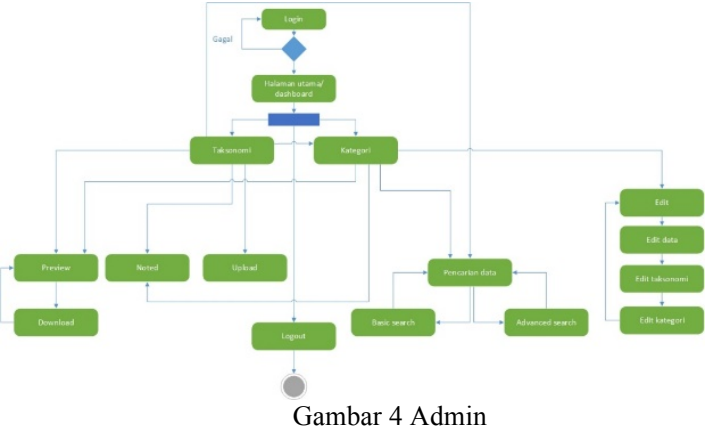

2. User

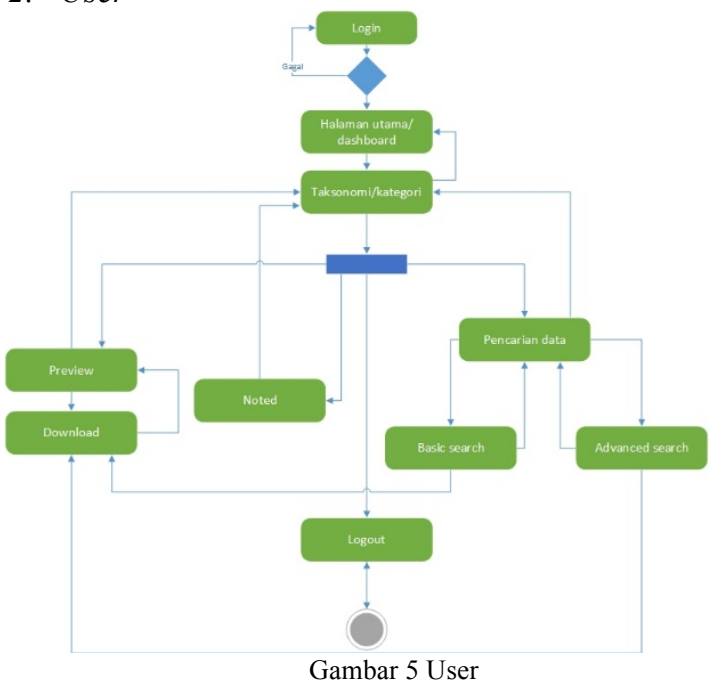

Activity diagram pada perancangan aplikasi ini dibuat menjadi 2 bagian, yaitu bagian administrator dan bagian pengguna biasa. Pembagian ini dikarenakan ke dua User tersebut mempunyai hak ases yang berbeda sehingga penggambarnya dibedakan juga. Gambar 4 menggambarkan Activity diagram untuk admin sedangkan Gambar 5 menggambarkan Activity diagran untuk User.

\section{Deployment diagram}

Deployment diagram menggambarkan detail bagaimana komponen di luncurkan (deploy) dalam infrastruktur sistem, di mana komponen akan terletak (pada mesin, server atau piranti keras).

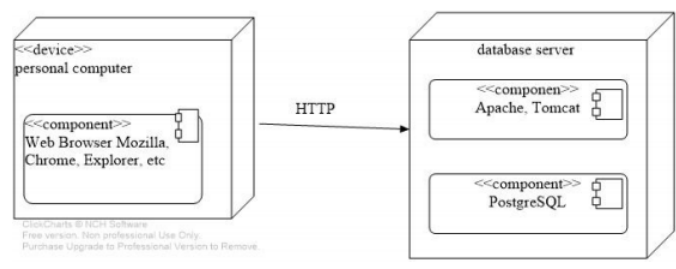

Gambar 6 Deployment diagram

Pada Gambar 6 Deployment diagram menggambarkan aplikasi akan disimpan dalam sebuah database server. Didalam database server terdapat componen apache, tomcat dan postgreSQL. Selanjutanya personal komputer akan meminta data menggunakan service HTTP untuk nantinya aplikasi ditampilkan di web browser.

\section{E. Perancangan antarmuka}

Perancangan antarmuka merupakan sebuah penggambaran, perencanaan, dan pembuatan sketsa atau pengaturan dari beberapa elemen yang terpisah ke dalam satu kesatuan yang utuh dan berfungsi. perancangan antarmuka dari aplikasi ini adalah gambaran dari halaman antarmuka dengan pengguna yang nanti akan dikembangkan [8]. Berikut perancangan antarmuka yang akan dibuat.

1. Halaman Login

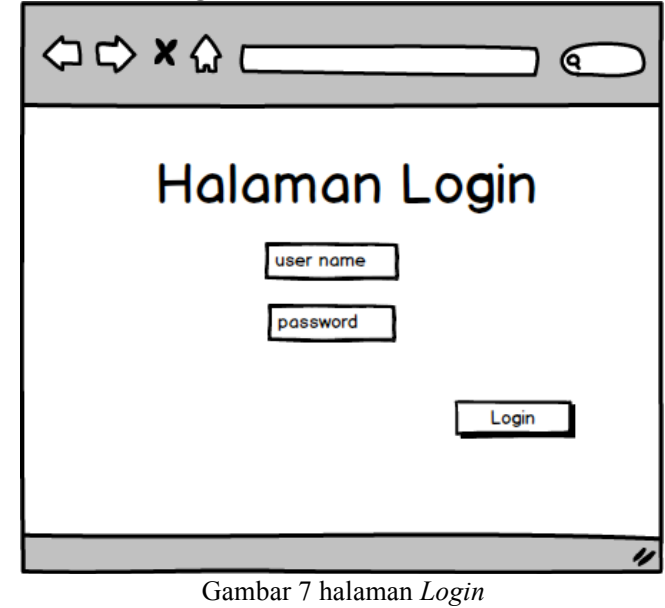

Gambar 7 menggambarkan Halaman Login yang berisikan input text yang digunakan untuk memasukan Username dan password pengguna, selain itu ada tombol Login yang digunakan untuk masuk ke halaman selanjutnya apabila pengguna sudah mengisi Username dan password dengan benar.

\section{Halaman utama}
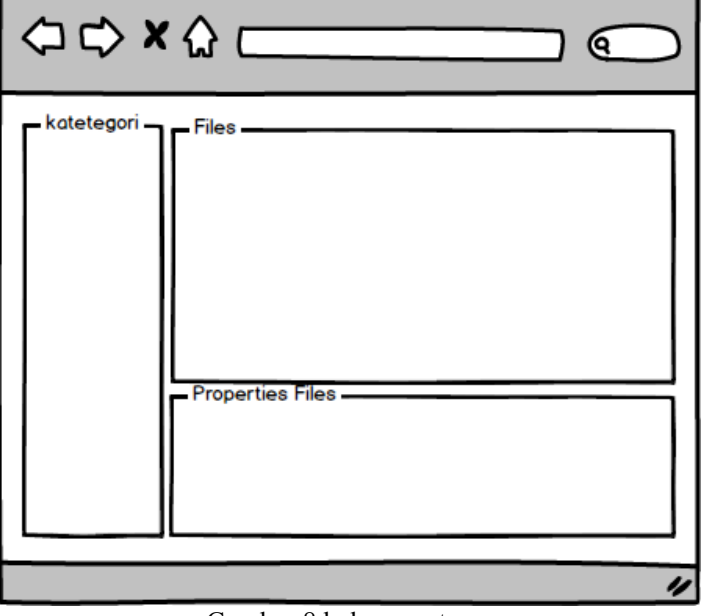

Gambar 8 halaman utama 
Pada gambar 8 menggambarkan halaman utama pengguna akan diberikan antarmuka yang digunakan untuk Preview, Edit Data, Edit Folder, dan Edit Kategori dan lain-lain. pengguna dengan mudah memanipulasi semua data baik folder maupun file dihalaman ini.

\section{Halaman pratinjau berkas}

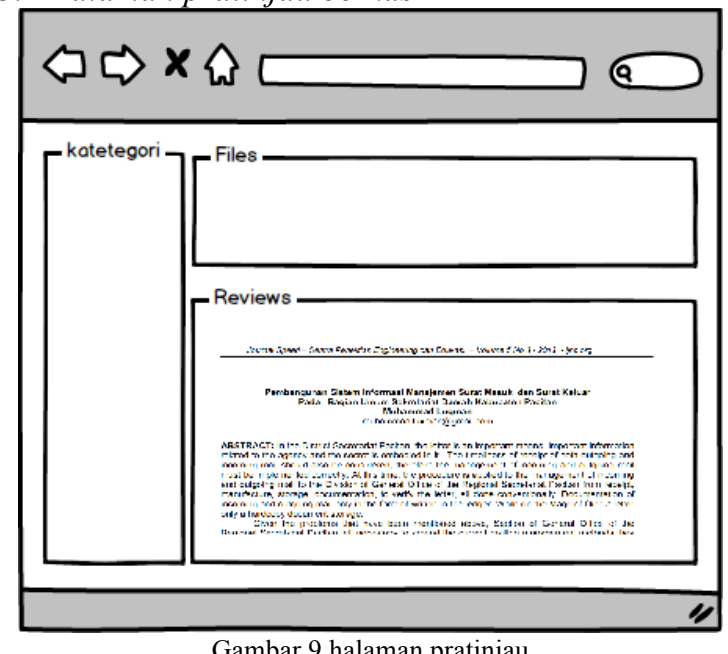

Gambar 9 Halaman pratinjau digunakan untuk menampilkan pratinjau berkas ataupun file yang telah diupload oleh User. File yang telah diupload bisa langsung dilihat dimenu ini tanpa harus mendownload terlebih dahulu

\section{KESIMPULAN}

Setelah dilakukan pembuatan sistem manajemen pengetahuan ini, maka dapat disimpulkan beberapa hal yang penting bahwa Perancangan Sistem informasi manajemen knowledge telah dibangun dan memenuhi spesifikasi kebutuhan dalam pengelolaan manajemen berkas. Perancangan Sistem informasi manajemen knowledge telah tersedia dalam bentuk berbasis web sehingga bisa diakses oleh pihak yang berkepentingan dari mana saja dan kapan saja.

Saran untuk penelitian selanjutnya adalah diharapkan bisa mengembangkan perancangan aplikasi berbasis mobile, sehingga bisa digunakan bersifat mobile. Selain itu membuat aplikasi mobile dengan database yang saling terintegrasi dengan aplikasi yang berbasis web.

\section{DAFTAR PUSTAKA}

[1] S. Fatwan, "Knowledge management warna cerah dunia bisnis," SWA, vol. 4 , no. 22 , p. 53,2006

[2] N. Kosasih and S Budiani, "Pengaruh Knowledge Management Terhadap Kinerja Karyawan : Studi Kasus Departement," pp. 80-88, 2004.

[3] I. Sommerville, Software Engineering (Rekayasa Perangkat Lunak). Jakarta: Erlangga, 2011.

[4] D. Nurdiana, M. Fajar, D. Rahadian, P. Sidiq and N.A. Hamdani,
"Development of General Transportation Applications in Garut City web-based," Journal of Physics : Conference Series, vol. 1280, no. 2, p. 22033, 2019.

[5] S. Dharwiyanti , "Pengantar Unified Modeling Language (UML)," pp $1-13,2003$.

[6] A. Hendini, "Pemodelan UML Sistem Informasi Monitoring Penjualan dan Stok Barang ( Studi Kasus : Distro ZHEZHA Pontianak )," vol. 4, no. 2, pp. 107-116, 2016.

[7] M. CHEN, "UML Activity Diagram Based Automatic Test Case Generation For Java Programs," Comput. J, vol. 52, no. 5, pp. 545-556, 2009 .

[8] A. A. Saputra, Perancangan Perangkat Sistem Keamanan Menggunakan Sensor PIR Dan Metode Background Substraction untuk Deteksi Pergerakan Manusia Pada Perumahan.: Universitas Muhammadiyah Gresik, 2019. 